\title{
Effect of Zinc and Boron on Growth and Yield of Onion under Temperate Conditions
}

\author{
Tariq A. Bhat ${ }^{1 *}$, M.A. Chattoo ${ }^{1}$, F. Mushtaq ${ }^{1}$, F. Akhter ${ }^{2}$, S.A. Mir ${ }^{3}$, \\ M.Y. Zargar ${ }^{4}$, K.P Wani ${ }^{1}$, M.D. Shah ${ }^{1}$ and Ejaz, A. Parry
}

${ }^{1}$ Division of Vegetable Science, ${ }^{2}$ Division of soil Science, ${ }^{3}$ Division of Agri. Stat, ${ }^{4}$ Division of Microbiology, Faculty of Horticulture, Sher-e-Kashmir University of Agricultural Sciences and Technology of Kashmir, Srinagar, Jammu and Kashmir-190001, India

${ }^{5}$ Division of fruit science, Faculty of Horticulture, Sher-e-Kashmir University of Agricultural Sciences and Technology of Kashmir, Srinagar, Jammu and Kashmir, 190001

*Corresponding author

\begin{abstract}
Keywords
Onion, Growth, Bulb yield, Zinc and boron

Article Info

Accepted:

30 February 2018

Available Online:

10 April 2018 factors with four levels of each viz., $Z$ inc $(Z), Z_{0}$ (control or no zinc), $Z_{1}(2.500 \mathrm{~kg}$ $\left.\mathrm{ha}^{-1}\right), \mathrm{Z}_{2}\left(5.00 \mathrm{~kg} \mathrm{ha}^{-1}\right)$ and $\mathrm{Z}_{3}\left(7.500 \mathrm{~kg} \mathrm{ha}^{-1}\right)$ and Boron (B), $\mathrm{B}_{0}$ (control or no boron), $B_{1}\left(0.500 \mathrm{~kg} \mathrm{ha}^{-1}\right), \mathrm{B}_{2}\left(1.000 \mathrm{~kg} \mathrm{ha}^{-1}\right)$ and $\mathrm{B}_{3}\left(1.500 \mathrm{~kg} \mathrm{ha}^{-1}\right)$. The observations were recorded on growth, yield and quality from 10 randomly selected plants of each treatment. Pooled analysis revealed significantly maximum values for plant height $(66.07 \mathrm{~cm})$, number of leaves plant ${ }^{-1}(10.61)$ and leaf length $(41.36 \mathrm{~cm})$ as compared to other levels including control. Similarly application of boron @ $\mathrm{B}_{3}\left(1.500 \mathrm{~kg} \mathrm{ha}^{-1}\right)$ recorded significantly maximum values for plant height $(64.67 \mathrm{~cm})$, No of leaves plant $^{-1}(10.38)$ and leaf length $(41.08 \mathrm{~cm})$ while significantly lowest values for plant height $(58.69 \mathrm{~cm})$, No of leaves plant ${ }^{-1}(9.06)$ and leaf length $(38.63 \mathrm{~cm})$ were recorded in control. Pooled analysis revealed that zinc @ $7.500 \mathrm{~kg} \mathrm{ha}^{-1}\left(\mathrm{Z}_{3}\right)$ recorded maximum values for polar diameter $(6.31 \mathrm{~cm})$, equatorial diameter $(6.32 \mathrm{~cm})$, average bulb weight $(82.64 \mathrm{~g})$ and total bulb yield $\left(275.50 \mathrm{q} \mathrm{ha}^{-1}\right)$ followed by $Z_{2}(5.000 \mathrm{~kg}$ $\left.\mathrm{ha}^{-1}\right)$. Similarly application of boron @ $1.500 \mathrm{~kg} \mathrm{ha}^{-1}\left(\mathrm{~B}_{3}\right)$ recorded significantly maximum values for polar diameter $(5.95 \mathrm{~cm})$, equatorial diameter $(6.14 \mathrm{~cm})$, average bulb weight $(81.15 \mathrm{~g})$ and total bulb yield $\left(270.29 \mathrm{q} \mathrm{ha}^{-1}\right)$.
\end{abstract}

A B S T R A C T

An investigation was performed at the experimental field of Sher-e-Kashmir University of Agricultural Sciences and Technology of Kashmir (SKUAST-K) during Rabi 2015-16 and Rabi 2016-17 to find out the effect of different levels of zinc and boron on growth, yield and quality of onion. The experiment was laid out in Randomized completely block design with three replications comprising of two 


\section{Introduction}

Onion (Allium cepa L.) is one of the most important commercial vegetable crops cultivated extensively in India. Onion is the most widely cultivated species of the genus Allium. It belongs to family Alliaceae. The edible bulb can grow up to $10 \mathrm{~cm}$ in diameter; it is composed of several overlapping layers on a central core. The edible portions of the bulb are the enlarged leaf bases and compact stem. Green onions also called scallions are eaten for their immature bulb and green foliage.

Onion is a cool season vegetable crop but is among the most widely adapted vegetable crops. They can be grown from the tropics to subarctic regions. This adaptation is primarily due to differing response to day length. Unlike most other species, day length influences bulbing in onions as opposed to flowering. Onion bulbs are placed into three groups based on their response to hours of day length. The short-day bulb varieties with day lengths of 11-12 hours while intermediate bulb varieties with day lengths of 13-14 hours and are found in the mid-temperate regions of this country; finally, the long-day varieties are adapted to the most northern climates with day lengths of 16 hours or greater.

Onion (Allium cepa L.), the "Queen of Kitchen" is one of the most important commercial crop not only in India but also in the world. Onion is cultivated under an area of 3991.51 ('000 ha) with a production of 76377.21 ('000 Mt) in the world (Anonymous, 2015). India ranks first in area and is the second largest producer of onion in the world, next to China, accounting for 22.18 per cent of the world area and 18.78 per cent of the world production. In India, onion is being grown in an area of 1274 ('000ha) with production of 21717.70 ('000 Mt) and the productivity is $17.04 \mathrm{t} \mathrm{ha}^{-1}$ which is low (Anonymous, 2015).
Productivity of onion were higher in the case of Turkey (34.3 Mt ha ${ }^{-1}$ ) followed by Brazil $\left(26.1 \mathrm{Mt} \mathrm{ha}^{-1}\right)$. In Kashmir it is grown under an area of 950 ha and produces $24250(\mathrm{Mt})$ with a productivity of $25.4 \quad\left(\mathrm{~T} \quad \mathrm{ha}^{-1}\right)$ (Anonymous, 2015). Due to lower yields, though India has the highest area under onion, it stands second in the production of onion in the world. Hence, there is a lot of potential for increasing the production of onion by improving the yields. India is also the largest exporter of onion and hence, it is crucial to improve the yields for enhancing the export level, so that it helps in earning foreign exchange for the exchequer of the country. Productivity could be increased by use of suitable varieties, balanced nutrition, optimum water management as well as need based plant protection measures. Among the many constraints for low productivity in onion, imbalanced nutrition is the main limiting factor.

Fertilizers offer the best means of increasing yield, quality and maintaining soil fertility. Results of various fertilizers have revealed that essential elements are important viz., nitrogen, phosphorus, potassium, sulphur, etc. In addition to nitrogen, phosphorus, potassium and sulphur, zinc as a micronutrient have great role in the fertilization program to achieve higher and sustainable bulb yields (Singh and Tiwari, 1995). Zinc is a micronutrient which is required for plant growth and development relatively in small amount. Zinc is involved in the formation of Chlorophyll and carbohydrate and is also involved in a diverse range of enzyme system. The functional role of zinc includes auxin metabolism, influence on the activities of dehydrogenase and carbonic anhydrate enzymes, synthesis of cytochrome and stabilization of ribosomal fractions (Tisdale et al., 1984). Zinc also plays very important role for grain formation and nutrition. Zinc deficiency is prevalent worldwide in temperate and tropical climates 
(Fageria et al., 2011). Zinc deficiency has been reported in soils of India and Kashmir (Mandal et al., 2000 and Wani et al., 2013). Application of zinc increased the growth and yield of onion (Phor et al., 1995).

Boron is essential for normal growth and production of sound and healthy vegetables. Boron has been linked with initiation and development of growing points, movement of sugars and starches to developing parts, movement of nutrient elements within the plant, formation of plant hormones affecting growth, root growth and health of fleshy roots, flower and fruit set and quality and flavor of vegetables (Vitosh et al., 2001). Boron is one of the important micronutrient for onion production and is essential for cell division, nitrogen and carbohydrate metabolism, protein formation and water relation in plant growth (Brady, 1990). Although it is quickly taken up from the soil, it is relatively immobile in the plant. It is important to maintain the correct balance of calcium, nitrogen and boron in the soil. High calcium and high nitrogen levels can reduce boron uptake. Boron deficiency has been observed in soils with high organic matter contents (Valk et al., 1989). Soils of Jammu and Kashmir are mostly dominated by Lithic or Typic Udorthents (Sidhu et al., 1999). These soils have already been reported to be deficient in boron (Mondal, 2002). The soils of Himalayas were found very low in boron (Khatri and Ghimire, 1992). Application of boron increases bulb size, weight per bulb and yield of onion (Smiriti et al., 2002). Keeping In view of above facts, the present study was undertaken to investigate the "Response of onion cv. Yellow Globe to different levels of zinc and boron under temperate conditions".

\section{Materials and Methods}

The investigation entitled "Response of onion cv. Yellow Globe to different levels of Zinc and Boron under temperate conditions" in Kashmir valley was carried out during Rabi 2015-16 and Rabi 2016-17 at Vegetable Experiment Farm, Division of Vegetable Science, SKUAST-K, Shalimar. The experiment was laid out in randomized Complete Block Design (RCBD), the total number of treatments were sixteen with three replications. The sixteen treatment combinations, $\mathrm{Z}_{0} \mathrm{~B}_{0}$ (No Zinc + No boron), $\mathrm{Z}_{0}$ $\mathrm{B}_{1}$ (No Zinc $+0.500 \mathrm{~kg}$ boron ha $\left.{ }^{-1}\right), \mathrm{Z}_{0} \mathrm{~B}_{1}$ (No Zinc $+0.500 \mathrm{~kg}$ boron $\left.\mathrm{ha}^{-1}\right), \mathrm{Z}_{0} \mathrm{~B}_{2}$ (No Zinc + $1.000 \mathrm{~kg}$ boron $\mathrm{ha}^{-1}$ ), $\mathrm{Z}_{0} \mathrm{~B}_{2}$ (No Zinc +1.500 $\mathrm{kg}$ boron ha $\left.{ }^{-1}\right), \mathrm{Z}_{1} \mathrm{~B}_{0}\left(2.500 \mathrm{~kg}\right.$ zinc ha ${ }^{-1}+\mathrm{No}$ boron), $\mathrm{Z}_{1} \mathrm{~B}_{1}\left(2.500 \mathrm{~kg}\right.$ zinc ha ${ }^{-1}+0.500 \mathrm{~kg}$ boron $\left.\mathrm{ha}^{-1}\right), \mathrm{Z}_{1} \mathrm{~B}_{2}\left(2.500 \mathrm{~kg}\right.$ zinc ha ${ }^{-1}+1.000$ $\mathrm{kg}$ boron $\left.\mathrm{ha}^{-1}\right), \mathrm{Z}_{1} \mathrm{~B}_{3}\left(2.500 \mathrm{~kg}\right.$ zinc $\mathrm{ha}^{-1}+$ $1.500 \mathrm{~kg}$ zinc ha $\left.{ }^{-1}\right), \mathrm{Z}_{2} \mathrm{~B}_{0}\left(5.000 \mathrm{~kg}_{\text {zinc ha }}{ }^{-1}+\right.$ NO boron), $\mathrm{Z}_{2} \mathrm{~B}_{1}\left(5.000 \mathrm{~kg}\right.$ zinc ha ${ }^{-1}+0.500$ $\mathrm{kg}$ boron $\left.\mathrm{ha}^{-1}\right), \mathrm{Z}_{2} \mathrm{~B}_{2}\left(5.000 \mathrm{~kg}\right.$ zinc $\mathrm{ha}^{-1}+$ $1.000 \mathrm{~kg}$ boron ha- $\left.{ }^{-1}\right), \mathrm{Z}_{2} \mathrm{~B}_{3}\left(5.000 \mathrm{~kg}\right.$ zinc ha ${ }^{-1}$

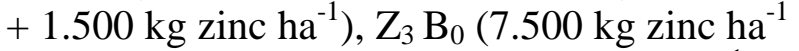
+ NO boron $), Z_{3} B_{1}\left(7.500 \mathrm{~kg}\right.$ zinc ha ${ }^{-1}+$ $0.500 \mathrm{~kg}$ boron ha $\left.{ }^{-1}\right), \mathrm{Z}_{3} \mathrm{~B}_{2}\left(7.500 \mathrm{~kg}\right.$ zinc ha ${ }^{-1}$ $+1.000 \mathrm{~kg}$ boron $\left.\mathrm{ha}^{-1}\right), \mathrm{Z}_{3} \mathrm{~B}_{3}(7.500 \mathrm{~kg}$ zinc $\mathrm{ha}^{-1}+1.500 \mathrm{~kg}$ zinc ha $^{-1}$ ).

The entire dose of FYM was applied as basal dose and thoroughly incorporated in the soil. The recommended dose of fertilizer for onion i.e., 120: 80: 60: 45 NPKS $\mathrm{kg} \mathrm{ha}^{-1}$, whole of phosphorus and potassium along with half dose of Nitrogen was applied at the time of sowing to plots in which recommended dose of fertilizer was to be applied. Moreover, zinc and boron were also applied to soil as per the treatments at the time of planting.

The remaining half dose of nitrogen was given as top dose after 128 days. Urea $(46 \% \mathrm{~N})$, Diammonium phosphate $\left(18 \% \mathrm{~N}, 46 \% \mathrm{P}_{2} \mathrm{O}_{5}\right)$, Muriate of potash (60\% KCL) and Gypsum (18\%), zinc sulphate (35\% Zn) and solubor $(20.5 \%$ B) were applied as sources of nitrogen, phosphorus, potassium, sulphur, zinc and solubor respectively. 


\section{Results and Discussion}

Pooled analysis of data over the years 2015-16 and 2016-17 revealed that plant height significantly increased with increasing levels of zinc. Significantly maximum plant height (66.07), number of leaves $\operatorname{plant}^{-1}$ (10.61) and leaf length $(41.36 \mathrm{~cm})$ was recorded with treatment $Z_{3}\left(7.500 \mathrm{~kg} \mathrm{Zn} \mathrm{ha}^{-1}\right)$ as compared to other treatments whereas control recorded significantly lower values for plant height $(56.52 \mathrm{~cm})$ number of leaves plant ${ }^{-1}(9.06)$, number of leaves per plant (9.06) and leaf length $(38.63 \mathrm{~cm})$ (Table 1). The increase in growth parameters with the application of zinc might be due to their role in the cell division and other physiological processes like photosynthesis, nitrogen metabolism etc. It helps in the biosynthesis of cytochrome and maintains plasma membrane integrity. Zinc modifies and/or regulates the activity of cabonic anhydrase, an enzyme that regulates the conversion of carbon dioxide to reactive bicarbonate species for fixation to carbohydrates in these plants. Zinc is also a part of several other enzymes such as superoxide dismutase and catalase, which prevents oxidative stress in plant cells. In addition to above zinc plays an important role in production of tryptophan which in turn is precursor of auxin, an essential growth hormone for plant growth. The results are in conformity with Lal and Maurya (1981); Jitendra et al., (1989); Gamili et al., (2000); Thakare et al., (2007); and Verma et al., (2014) in onion; Tiwari et al., (2003) in garlic and Mahesh and Sen in okra (2005).

Perusal of Table 1 reflected that pooled data over two different years 2015-16 and 2016-17 showed significant increase in polar diameter, equatorial diameter, average bulb weight and total bulb yield with increase in zinc level. Significantly maximum values for polar diameter $(6.31 \mathrm{~cm})$, equatorial diameter $(6.32$ $\mathrm{cm})$, average bulb weight $(82.64 \mathrm{~g})$ and total bulb yield (275.50 q ha $\left.{ }^{-1}\right)$ was registered with application of zinc at the rate of $7.500 \mathrm{~kg} \mathrm{ha}^{-1}$ as compared to lower levels of zinc including control treatment. The increase in bulb yield related parameters and total bulb yield of onion with the application of higher levels of zinc might be due to enhanced synthesis and translocation of photosynthates to the bulbs. Further the improvement of bulb yield was due to better vegetative growth as observed in the present study. This result corroborates the findings of Singh and Tiwari (1996) who reported that a high yield was a reflect of vigorous vegetative growth and healthy plants. Similar findings have also been reported in onion by Jawaharlal et al., (1986), Pena et al., (1999), Gamili et al., (2000), Kumar et al., (2000), Khan et al., (2007), Thakare et al., (2007), and Kurtz and Ernani (2010). The onion cv. Yellow Globe was significantly influenced with respect to growth parameters like plant height, leaf number and leaf length by boron levels. Application of boron $\left(\mathrm{B}_{3}\right)$ at the rate of $1.500 \mathrm{~kg} \mathrm{ha}^{-1}$ registered maximum plant height $(64.67 \mathrm{~cm})$, leaf number $(9.06)$ and leaf length $(38.63 \mathrm{~cm})$ which was statistically higher as compared to rest of treatments including control $\mathrm{B}_{0}$ (Table 2). The increase in growth parameters of onion with progressive increase in the application of boron might be due to their role in cell division, meristematic activity of plant tissue and expansion of cell (Patil et al., 2009). The favourable effect of boron on plant growth might also be due to its role in physiological processes such as carbohydrate and protein metabolism and cellular function within the plant. Since boron is mainly involved in the hormone development and stimulation or inhibition of specific metabolism pathways (Waqar et al., 2009). Boron may affect metabolic pathways by binding apoplastic proteins to cis-hydroxyl groups of cell walls and membranes, and by interfering with manganese-dependent enzymatic reactions (Dale and Krystyna, 1998). 
Table.1 Effect of different levels of zinc on growth and yield parameters of onion

\begin{tabular}{|c|c|c|c|c|c|c|c|}
\hline Zinc & $\begin{array}{l}\text { Plant height } \\
\text { (cm) }\end{array}$ & Leaf number & $\begin{array}{l}\text { Leaf length } \\
\qquad(\mathrm{cm})\end{array}$ & $\begin{array}{l}\text { Polar diameter } \\
\text { (cm) }\end{array}$ & $\begin{array}{c}\text { Equatorial } \\
\text { diameter (cm) }\end{array}$ & $\begin{array}{c}\text { Average } \\
\text { bulb weight } \\
\text { (g) }\end{array}$ & $\begin{array}{c}\text { Total bulb } \\
\text { yield }\left(\mathbf{q} \mathbf{h a}^{-1}\right)\end{array}$ \\
\hline $\mathbf{Z}_{0}$ & 58.69 & 9.06 & 38.63 & 4.92 & 5.13 & 74.34 & 247.54 \\
\hline $\mathbf{Z}_{1}$ & 62.41 & 9.48 & 40.25 & 5.45 & 5.55 & 75.35 & 252.77 \\
\hline $\mathbf{Z}_{2}$ & 63.06 & 9.90 & 41.08 & 5.82 & 5.87 & 80.51 & 268.58 \\
\hline $\mathbf{Z}_{3}$ & 66.07 & 10.61 & 41.36 & 6.31 & 6.32 & 82.64 & 275.50 \\
\hline C.D $(p \leq 0.05)$ & 0.65 & 0.17 & 0.17 & 0.09 & 0.15 & 0.67 & 1.86 \\
\hline S.E (m) & 0.22 & 0.06 & 0.06 & 0.03 & 0.05 & 0.22 & 0.64 \\
\hline
\end{tabular}

Table.2 Effect of different levels of boron on growth and yield parameters of onion

\begin{tabular}{|c|c|c|c|c|c|c|c|}
\hline Boron & $\begin{array}{c}\text { Plant height } \\
(\mathrm{cm})\end{array}$ & Leaf number & $\begin{array}{l}\text { Leaf length } \\
\qquad(\mathrm{cm})\end{array}$ & $\begin{array}{l}\text { Polar diameter } \\
(\mathbf{c m})\end{array}$ & $\begin{array}{c}\text { Equatorial } \\
\text { diameter }(\mathrm{cm})\end{array}$ & $\begin{array}{c}\text { Average } \\
\text { bulb weight } \\
\text { (g) }\end{array}$ & $\begin{array}{l}\text { Total bulb } \\
\text { yield }\left(\mathbf{q} \mathbf{h a}^{-1}\right)\end{array}$ \\
\hline $\mathbf{B}_{\mathbf{0}}$ & 60.71 & 9.18 & 39.59 & 5.16 & 5.18 & 75.24 & 250.83 \\
\hline $\mathbf{B}_{1}$ & 61.89 & 9.58 & 40.06 & 5.82 & 5.62 & 77.39 & 257.98 \\
\hline $\mathbf{B}_{2}$ & 62.96 & 9.92 & 40.58 & 5.85 & 5.92 & 79.62 & 265.29 \\
\hline $\mathbf{B}_{3}$ & 64.67 & 10.38 & 41.08 & 5.95 & 6.14 & 81.15 & 270.29 \\
\hline C.D $(p \leq 0.05)$ & 0.65 & 0.17 & 0.17 & 0.09 & 0.15 & 0.67 & 1.86 \\
\hline S.E (m) & 0.22 & 0.06 & 0.06 & 0.03 & 0.05 & 0.22 & 0.64 \\
\hline
\end{tabular}


Boron is functionally important in forming a pectic network in cell wall which is responsible for the extensibility of cell wall and consequently regulates cell growth (Yang and Yiqin, 1999). Further boron regulates the activity of ascorabate and dehydroascorbate which losses cell wall and thus giving more space to grow and increase the elongation and meristematic regions in onion (Naqib and Jahan, 2017). Similar findings were also reported by Maurya and Lal (1975), Abou ElMagd et al., (1989), Smriti et al., (2002), Salam et al., (2004), Rashid et al., (2007) in onion; Howlader et al., (2010) and Chanchan et al., (2013) in garlic; Singh and Verma (1991) in tomato; Sharma (2002) in cauliflower. Interaction effect of zinc and boron was found significant in increasing plant height.

Significantly highest values for polar diameter $(5.95 \mathrm{~cm})$, equatorial diameter $(6.14 \mathrm{~cm})$, average bulb weight $(81.15 \mathrm{~g})$ and total bulb yield (270.29 q ha-1) was obtained when boron were applied at the rate of $1.500 \mathrm{~kg} \mathrm{ha}^{-1}$ in both 2015-16 and 2016-17, which was significantly superior to all the treatments including control and data is presented on Table 2. The increase in total bulb yield was 7.75 percent over control treatment $\left(\mathrm{B}_{0}\right)$.

This might be due to beneficial effect of boron on growth parameters which has increased yield and yield related parameters of onion. There may be favourable effects of boron on root development, formation of carbohydrates, regulation of water and translocation of photosynthates to bulbs from leaves. The higher photosynthesis accumulation in the bulbs would ensure higher individual bulb weight and large bulb diameter which collectively increases the bulb yield of onion. Similar finding were also reported by Mishra et al., (1990), Singh and Verma (1991) and Chattopadhyay and Mukhopadhyay (2004) in onion.

\section{References}

Abou El-Magd, M.M., Bakry, M.O. and Shaheen, A.M. 1989. Effect of Boron Foliar spray on the seed yield of onion. journal of Agricultural Research 12: 31-39.

Anonymous, 2016. Information Status of Vegetables, Spices, and Mushroom of Kashmir Division. Agriculture Department Jammu and Kashmir.

Anonymous. 2015. Directorate of economics and statistics, New Delhi- Horticulture Division, Ministry of Agriculture, Govt. of India. Market intelligence system 2014-2015. pp. 11-13.

Brady, N. C. 1990. The nature and properties and soils. 10th edition, A.K. Ghosh. Printing-Hall of India Pvt. Ltd., New Delhi pp. 383.

Chanchan, M., Hore, J. K. and Ghanti. S. 2013. Response of garlic to foliar application of some micronutrients. Journal of Crop and Weed 9:138-141.

Chattopadhyay, A. and Mukhopadhyay, R. 2004. Response of onion to boron as foliar feeding. Indian Journal Ornamental Horticultre 11: 21-27.

Dale, G. B. and Krystyna, M. 1998. Boron in plant structure and function. Plant Physiology 49:481-500.

Fageria, N. K., Dos, S. and Cobucci, T. 2011. Zinc nutrition of lowland rice. Communication in Soil Science and Plant Analysis 42: 1719-1727.

Gamelli, E. L., Hanna, N. and Hadi, E. L. 2000. The effect of some foliar fertilizers application on growth, bulb yield, quality and storage ability of onion. Journal of Horticulture 12: 3038.

Howlader, M.M., Kamruzzaman, M. M. Chowdhury, M. E. and Yousuf, M. N. 2010. Effect of phosphorus, potassium and boron on onion seed production. Research Report. Spices Research 
Centre. Bangladesh Agricultre Research Instituite. pp.13-17.

Jawaharlal, M., Sundaranajan, S. and Veeraraga, O. 1986. Studies on the mode of application of zinc and iron on the growth and yield of onion (Allium cepa var, cepa). South Indian Horticultre 34:236-239.

Jitendra, S., Dhankar, B.S. and Singh. J. 1989. Effect of nitrogen, Potash and Zinc on growth yield and quality of onion. Vegetable Science 16:136-144.

Khan, A.A., Zubair, M., Bari, A. and Maula, F. 2007. Response of onion (Allium cepa) growth and yield to different levels of nitrogen and zinc in swat valley. Sarhad Journal of Agriculture 23: 933-936.

Kurtz, C. and Ernani, P. R. 2010. Onion Yield Influenced by Micronutrient Application. Revista Brasileira de Ciencia do Solo 34: 133-142.

Lal, S. and Maurya, A.N. 1981. Effect of zinc on onion. Haryana Journal of Horticultre Science 10: 231-235.

Mahesh, K. and Sen, N.L.2005. Interaction effect of zinc and boron on okra (Abelmoschus Esculentus L.). Agriculture science digest 24: 307 308.

Mandal, B., Hazra, G.C. and Mandal, L.N. 2000. Soil management influences on zinc desorption for rice and maize nutrition. Soil Science Society of America Journal 64: 1699-1705.

Maurya, A.N. and Lal. S. 1975. Response of onion (Allium cepa L.) to zinc feeding. Punjab Horticultre Journal 15:61-64.

Mishra, H.P., Singh, K.P. and Yadow, J.P. 1990. Influence of zinc, iron, boron and manganese and their uptake on onion (Allium cepa L.) growth in calcareous soil. Haryana Journal of Horticulture Science 19: 153- 159.

Mondal, A. K. 2002. Studies on boron in relation to quality and production of apple at Bhaderwah. Environment and Ecology 20: 611-613.

Naqib, S.A. and Jahan, M.S.2017. The function of molybdenum and boron on the plants. Journal of Agricultural Research 2:136-141.

Patil, V.K., Yadlod, S.S., Tambe, T.B. and Narsude, P.B. 2009. Effect of foliar application of micronutrients on flowering and fruit set of tomato (Lycopersicon esculentum Mill. cv. Phule Raja). International Journal of Agricultural Sciences 6(1): 164-166.

Phor, S.K., Pandey, U.C. and Verma, U. 1995. Effects of zinc on the growth and yield of garlic (Allium sativum L). Crop Research 9: 286-291.

Rashid, A. M., Khan, A. M. and Ullah, M. A. 2007. Effect of sulphur and boron on onion seed production. Research Report. Spices Research Centre. Bangladesh Agriculture Research 5: 911.

Salam, M. A., Siddique, M. A. and Goffar, M. A. 2011. Quality of tomato as influenced by boron and zinc in presence of different doses of cowdung. Bangladesh Journal Agricultre Research 36: 151-163.

Sidhu, G. S., Rana, K. P., Walia, C. S., Mahapatra S. K. and Lal, T. 1999. Characteristics and classification of some dominant soils of Jammu region for land use planning. Agro pedology 9: 22- 29.

Singh, D.P. and Tiwari. R.S. 1996. Effect of micro-nutrients on yield and quality of Onion (Allium cepa L) variety Pusa Red. Recent Horticulture 3:111-117.

Singh, S. H. and Verma, S. K. 1991. Influence of potassium, zinc and boron on growth and yield of tomato (Lycopersicon esculentum Mill.). Vegetable Science 18:122-129.

Smriti, S., Kumar, R. and Singh, S. K. 2002. Effect of Sulphur and Boron nutrition 
on growth, yield and quality of onion. Journal of Applied Biology 12: 40-46.

Tisdale, S. L., Nelson, W. L. and Beaten, J. D. 1984. Zinc. Soil Fertility and Fertilizers. Macmillan Publishing Company, New York. Fourth Edition pp. 382-391.

Tiwari, R.S., Ankur, A. and Sengar, S.C. 2003. Effect of bioregulators on growth, bulb yield, quality and storability of onion cv.Pusa Red. Indian Journal of Plant Physiology 8(4):411-413.

Valk, V. and Bruin, P. N. A. 1989. Nutrition of tulips on fresh soil: Boron application limits early losses. Bloem Bollen Cultuur 100: 44-45.

Verma, S. K., Singh, S. S. and Awasthi, C. P. 1995. Response of zinc and boron fertilization on yield and quality fruits at different stages of picking. Vegetable Science 22: 5-8.
Vitosh, M. L. Warncke D. D. and Lucas, R. E. 2001. Secondary and micronutrients for vegetables and field crops. Crop and Soil Sciences 5: 18-36

Wani, M. A., Wani, J. A., Bhat, M. A., Kirmani, N. A, Wani, Z. M., Bhat, M. A. and Nazir, S. 2013. Mapping of soil micronutrients in Kashmir agricultural landscape using ordinary kriging and indicator approach. Journal of the Indian Society of Remote Sensing 41: 319-29.

Waqar, A., Niaz, A., S. Kanwal, R. and Khalid, R.2009. Role of boron in plant growth. Journal of Agriculture Research 2: 47-52.

Yang, X. and Yiqin, L.1999. Boron plays an important role in the regulation of plant cell growth. Tsinghua Science and Technology 4: 1583-1586.

\section{How to cite this article:}

Tariq A. Bhat, M.A. Chattoo, F. Mushtaq, F. Akhter, S.A. Mir, M.Y. Zargar, K.P Wani, M.D. Shah and Ejaz A. Parry. 2018. Effect of Zinc and Boron on Growth and Yield of Onion under Temperate Conditions. Int.J.Curr.Microbiol.App.Sci. 7(04): 3776-3783. doi: https://doi.org/10.20546/ijcmas.2018.704.425 